\title{
Cameroon's neopatrimonial dilemma
}

\section{Working Paper}

Author(s):

Gabriel, Jürg Martin

Publication date:

1998

Permanent link:

https://doi.org/10.3929/ethz-a-001990933

Rights / license:

In Copyright - Non-Commercial Use Permitted

Originally published in:

Beiträge / Eidgenössische Technische Hochschule, Forschungsstelle für Internationale Beziehungen 20 


\title{
Center for International Studies, Zurich \\ Zentrum für Internationale Studien, Zürich
}

\author{
Jürg Martin Gabriel
}

\section{Cameroon's Neopatrimonial Dilemma}

\author{
Beiträge \\ Nr. 20 / August 1999 \\ 2., erweiterte Auflage
}

Forschungsstelle für Internationale Beziehungen

Eidgenössische Technische Hochschule Zürich 


\section{Table of Contents}

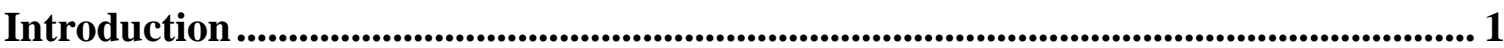

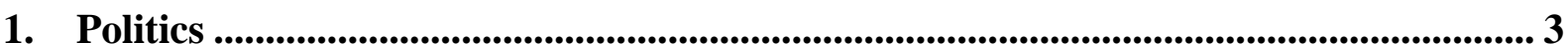

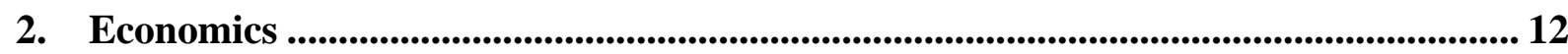

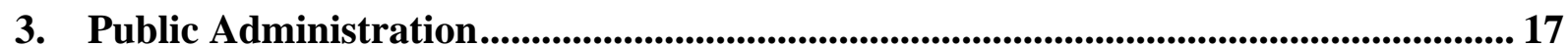

4. Neopatrimonialism and Cameroon....................................................................... 22 


\section{About the Author}

Jürg Martin Gabriel is currently Professor of International Relations at the Swiss Federal Institute of Technology (Center for International Studies, CIS) in Zurich, Switzerland. He was previously a Professor of International Relations at the University of St. Gallen, Switzerland, a Lecturer at the University of Zurich, Assistant Professor at the Université de Yaoundé in Cameroon, and, in 1991-1992, Visiting Professor at Stanford University, California. 


\section{Introduction}

Of the 47 sub-Saharan states, only a few have not suffered from coups or civil wars; Cameroon is one of these. It has had two presidents, and the transfer of power was constitutional. In addition, Cameroonian politics have become more liberal in recent years: the single-party system was abandoned in favor of multipartyism, and parallel to the governmental information channels, there is now a lively printed press. In comparison with other African countries, Cameroon is a rare case of pluralism and stability.

But the country has also experienced instability. In the 1960s, the government of Ahmadou Ahidjo faced a rebellion fomented by neo-Marxist guerillas. While the 1970s were a period of relative calm, there were a number of minor disturbances, mainly among students. In the 1980s, President Paul Biya had to deal with an assassination plot and an open military rebellion, and in the 1990s, as I will show later in more detail, political protest has been frequent. Political unrest is not uncommon in Africa, but in the case of Cameroon there is an interesting blend of stability and instability ? a phenomenon closely related to what contemporary political scientists identify as neopatrimonialism. It is a highly personal and clientelistic type of rule involving the massive redistribution of state resources.

As French scholars pointed out as early as the 1970s, neopatrimonialism is a form of governance typical of Cameroon but also of most African countries (Médard 1977: 35-84). More recently, American political scientists have taken a closer look at Cameroon and at neopatrimonialism, mainly in the context of regime change or the recent attempts at democratization. In the early nineties, Nicolas van de Walle wrote an article on neopatrimonial regime transition that made specific reference to Cameroon (1994: 129-57), and three years later he and Michael Bratton published a general - and impressive - study on the role of 
neopatrimonialism in regime transition (1997: 61-96).

According to Bratton and van de Walle, neopatrimonialism typically produces both stability and instability, thereby creating a veritable dilemma. By constructing extensive clientelistic networks to maintain power, African presidents create a degree of stability, but the massive use of state resources required to meet clientelistic needs helps to undermine the very stability that the system generates. Van de Walle therefore concludes that such political systems are not only economically ineffective but also produce the tensions that result in demands for change (1994: 131).

While this is no doubt true, the African experience shows that the combination of stability and instability can vary greatly. Nigeria, Cameroon's direct neighbor, has all the characteristics of a neopatrimonial regime and suffers from the same inherent dilemma - yet much more dramatically. Compared to many other African countries, Cameroon has managed its neopatrimonial dilemma in a relatively conservative fashion. On the negative side, this has resulted in what Bratton and van de Walle call a 'flawed' transition, because liberalization has not led to democracy (1997: 120), but on the positive side, some of the excesses typical of other countries were avoided. Not for the first time, Cameroon manages to 'muddle through' by exhibiting a degree of sluggishness in both politics and economics that is astounding and that calls for explanation. The purpose of this article is to find a possible answer by isolating factors that might account for the peculiarities of the country's politics. Basically I will stay within the framework developed by Bratton and van de Walle, because I consider it highly useful. On one or two points, however, it will be necessary to deviate and to show the unique features of Cameroonian politics.

The article has four parts. Since neopatrimonial rule is an intricate mixture of politics and economics, the article will focus on the political economy of Cam- 
eroon. For the purpose of this essay the term comprises politics, economics and public administration, the latter being of particular importance for an understanding of the neopatrimonial dilemma. The first part, therefore, is devoted to politics in the narrow sense of the term and contains a brief summary of its main features and some of the more important events. The story has been told many times and in more detail (Prouzet 1974; Bayard 1985), but a brief summary is necessary in order to make the argument.

In the second part I will sketch Cameroon's economic troubles, and in the third, the focus is on the poor performance of public administration or the lack of 'good governance'. The information stems in part from Cameroonian publications, which have recently become more numerous, and from my own sources. They also emante from the World Bank and from a recent study by Jeffrey Sachs of the Harvard Institute for International Developmental. In the fourth and final part, the various strings are pulled together in order to discuss the peculiarities of the Cameroonian neopatrimonial dilemma.

\section{Politics}

Compared to most of its neighboring countries, Cameroon is a political success story. Nigeria and Chad have known civil war and several coups d'états; the Central African Republic is practically a failing state in which France has intervened on a regular basis; Equatorial Guinea has experienced brutal dictatorship, a situation that has still not much improved. Only Gabon to the south enjoys similar peace and stability. Cameroon's two presidents to date, Ahmadou Ahidjo (196082) and Paul Biya (1982-), have both managed to keep the country from joining the ranks of failing states. Before discussing the problems of Cameroonian politics, it is important to highlight some of the obvious achievements. 
The roots of Cameroonian stability are not self-evident. There is hardly another African country with greater diversity in terms of ethnic groups, languages and religions. Experts count over 200 ethnic groups comprising various types of Bantus in the south, Semi-Bantus on the Adamawa Plateau (or the Grassfields) in the west, as well as Fulbés (Peuls) and Kirdis in the north. ${ }^{1}$ The peoples of the north tend to be Muslim, those of the south and the west Christian, but there are large numbers of animists. Needless to say, Cameroon's inner and outer boundaries were drawn arbitrarily by the colonial masters and cut across ethnic lines.

Colonization added to the diversity because the once German 'Kamerun' was split into two protectorates under the League of Nations - British Cameroon in the west, and French Cameroon in the east. After independence, the two parts were reunited, and since then both French and English are not only official languages but are also used ? although to varying degrees in various places. Furthermore, pidgin is widely spoken along the coast, even in French-speaking Douala. Cameroon's great ethnic diversity is therefore accompanied by a unique lingusitic and cultural pattern which, as I will demonstrate later on, is particularly complex in politically sensitive areas like Douala and the Grassfields.

As if such diversity were not enough, the country was also divided along ideological lines at the time of independence. The communist-inspired Union des Populations du Cameroun (UPC) was in violent revolt against the Ahidjo regime, which was backed by de Gaulle. The president's first task was to build up a strong army and to put down a guerilla war. From the beginning, Ahidjo's rule was autocratic (Jackson and Rosberg 1982: 152-56) and quickly developed the three central features of neopatrimonial rule mentioned by Bretton and van de Walle: presidentialism, clientelism and the massive redistribution of state resources (1997: 61-68).

Under Ahidjo, presidentialism meant the almost total concentration of power around one person and one institution - 'la présidence' (Prouzet 1974: 151-86; 
Bayart 1985: 141-59). As a true pater familias, Ahidjo saw himself as the father of the new nation and as the 'guide suprême' who would lead it toward development. He cultivated the image of a stern and proud person regularly 'lecturing' to the nation over the radio. Compared to other African presidents, his personal life style was modest, but when he appeared in public a few luxurious Mercedes and a score of BMW motorcycles were 'de rigeur'. He carried various official and unofficial titles, and once he had been to Mecca, 'El Hadj' was added to the others. There was a pronounced personality cult, and Ahidjo seemed to consciously promote an image of mystique and secrecy (Prouzet 1974: 230-34). His style of government was entirely personal and nonbureaucratic. It became a custom under Ahidjo - followed to this day - to announce the regular reassignment of hundreds if not thousands of government positions via governmental radio!

Ahidjo built up a large clientelistic network reaching into practically every corner of the country. People got their jobs, their licenses, contracts or projects through him and were expected to show appropriate gratitude. Loyalty to the president was more important than performance on the job; as a result, the private good had priority over the public good. Such patronage implied massive distribution of state resources, most of which could not be raised at home, because the government's internal extraction capacity was minimal. When oil revenues began to flow in the latter part of the 1970s, more funds became available, but they were largely deposited abroad, remained a state secret, and the president kept direct control over the money (van de Walle 1994: 141). In short, Ahidjo's style of government was in most ways very traditional and reminded many of the Fulbé sultans (lamido, lamibés) of his native region.

To a large extent, however, clientelistic politics were financed from nonCameroonian sources. France was an important provider of funds, as were many other European countries, the United States, and the usual array of international organizations concerned with development. During the Cold War, the flow of 
foreign money was quite generous, and if the donors in East and West were not overly forthcoming, Ahidjo was a master at playing them off against each other.

Clientelism went hand in hand with the formation of a multi-ethnic ruling class that to this day includes representatives from practically all parts of the country. Although Ahidjo himself was from the north, the country did not go the 'Nigerian way' and develop a tradition of northern primacy, be it civilian or military (Joseph 1999: 360-362). On the contrary, Cameroon conforms closely to the pattern of peaceful interethnic conflict management recently suggested by Rothchild (1999: 322-23). Given the great cultural diversity of the country, Ahidjo may not have had any other choice; no single group seems large enough to monopolize power. Whatever the reason, multi-ethnic elite politics have since been a Cameroonian reality (Le Vine 1986: 20-52; Prouzet 1974: 51-58, 85-126).

According to Pierre Flambeau Ngayap there are two levels of elite integration: a 'macroéquilibre géopolitique' and a 'microdosage régional'. At the macro-level, the 'présidence', the cabinet and especially the 'ministres d'états' have at all times been composed of representatives of all major regions and ethnic groups. Appointing both speakers of English and French to important posts deftly bridges the francophone-anglophone division. Ahidjo and Biya, both francophone, have often chosen English-speaking prime ministers or vice presidents. ' 'Microdosage' shows at the provincial level, where the more important positions are deliberately assigned to representatives of all 'départements'. Furthermore, and in order to promote integration, regional provincial offices are often headed by non-locals (Ngayap 1983: 68-87).

This has not prevented both Ahidjo and Biya from appointing friends from their own ethnic groups to head some of the more sensitive posts, particularly in the area of security. In contrast to some other countries, however, power in Cameroon has never been monopolized by one ethnic group. Ahidjo was a Muslim from the 
north (Foulbé), and Biya is a Christian from the south (Bëti), but their tribes always shared power with others. From the vantage point of many critics, the problem in Cameroon is not that one group 'has its hand in the public till' - but that all of them do! This is not atypical of neopatrimonialism and clientelistic networks, but in Cameroon the art has reached unprecedented levels of perfection. It has the advantage of pacifying a highly complex polity but entails the obvious disadvantages of waste, mismanagement and economic stagnation.

If tribalism has not driven Cameroon apart, it is nonetheless a most powerful political force. The existing equilibrium is real but also precarious, and ethnic thinking penetrates all spheres of life, including government, parties and newspapers (Mbock 1990: 66-110). Elite pluralism is not spontaneous but has to be enforced from the top. This is facilitated by a heavy degree of power centralization.

From 1961 to 1972, Cameroon was a federation composed of two relatively autonmous parts, one francophone, the other anglophone. But in 1972, Ahidjo abolished the two entities and launched the United Republic of Cameroon. ${ }^{3} \mathrm{He}$ also established a single-party regime by creating the Union Nationale Camerounaise (UNC), a move that guaranteed uncontested elections at all levels (Prouzet 1974: 327-52). The party's official purpose was to promote development while guaranteeing national unity. Many anglophones were not pleased by the changes, but the most important figures had been co-opted long before. With this dual move, Ahidjo's personal power reached new heights.

In a true neopatrimonial state there is no room for political autonomy of any sort; federalism and multipartyism therefore had to be abolished. ${ }^{4}$ The existence of a modern civil society is equally incompatible, because it implies autonomous intermediary groups willing to engage in political decision-making. To this day, Cameroon has no forceful professional organizations, unions, bar associations or human rights movements (Bratton and van de Walle 1997: 147-49, 249-55). ${ }^{5}$ 
Autonomy is at most associated with the discretionary and arbitrary exercise of public office.

In 1982, to everyone's surprise, Ahidjo voluntarily resigned and handed power over to his Prime Minister, Paul Biya. It was one of those rare cases of constitutional power transition in Africa, although within eighteen months Biya had to fight off a conspiracy and a coup d'état by the Presidential Guard. He handled both situations without the excessive use of force (Eboua 1996; Ndi Mbarga 1993: 11-26; Le Vine 1986: 20-52). When it comes to having recourse to violence, there is a clear distinction between clientelistic autocrats and ruthless dictators. Both Ahidjo and Biya belong to the former and not the latter (Jackson and Rosberg 1982: 14-82).

Today, Cameroon is a multiparty state with dozens of newspapers and contested elections. ${ }^{6}$ However, this was not the doing of the new president. Biya, upon taking office, spoke vaguely of more freedom and made the single party sound more liberal by naming it Rassemblement Démocratique du Peuple Camerounais (RDPC), but generally he continued Ahidjo's neopatrimonial rule. It was only after the Berlin Wall fell that demands for greater political freedom could no longer be resisted (Ndi Mbarga 1993: 11-121). Events in Europe played a part, yet only indirectly. More important were two other factors: political change in various Central- and West-African states and the 'crise' at home. As Michel Banock shows, it was events in Benin, Gabon, Zaïre and Ivory Coast that made a major impact. In all of these instances people took to the streets and demanded the convocation of 'national conferences' to change the political order (1992: 11$16)$.

Cameroonians, suffering from the 'crise' and disappointed over Biya's empty promises for political reform, were ripe for a change. There were stirrings in Douala in February 1990, but the first real upheaval occurred in May of the same 
year in Bamenda, the capital of the anglophone North-West Province, where John Fru Ndi organized a march and founded a new party, the Social Democratic Front (SDF). The government intervened and tried to stop the 'rebellion', but the dam had burst. From then on, the foundation of new parties and the publication of opposition newspapers were unstoppable (Banock 1992: 27-47; Ndi Mbarga 1993: 122-242).

According to Bratton and van de Walle, it is typical of neopatrimonial rule that demands for political liberalization are initiated by the masses and not the elites, through public protest rather than elite pressures (1997: 83). That is what happened in Cameroon; the fiscal crisis and economic stagnation hurt the masses more than the ruling circles. To be sure, some disgruntled members of the elite did join the opposition forces, but by and large Biya managed to maintain elite cohesion. This is an important point in understanding the peculiarities of Cameroonian neopatrimonialism, and I shall discuss it further in part four of this essay.

As a result of the protests, the political system was liberalized. The details of the process have been described in detail elsewhere (Takougang and Krieger 1998: 115-58; Mehler 1997: 95-138; Eboussi Boulaga 63-163). Today, there are three major parties and a large number of minor ones. The President's party, the RDPC, has branches all over the country, and the central committee, too, is representative of the entire nation. In various elections, however, it has been demonstrated that the RDPC's following is concentrated in the south, the east and the center, roughly the area where Biya is from. John Fru Ndi's SDF, too, has adherents in many parts of Cameroon but is strongest in the anglophone and francophone west and the Coastal area around Limbe, Buea and Douala. Finally, there is Bello Bouba Maïgari's UNDP (Union Nationale pour la Démocratie et le Progrès). Its home is the Muslim north, but it is not representative of the entire region. The remaining parties are small, do not count nationally and are often purely ethnic. But, and this must be emphasized, it is a simplification to argue that the three 
major parties divide neatly along ethnic lines and reflect 'tribalism'.

The first contested elections were held in 1992. In March there were parliamentary and in October presidential elections. In the former elections, the RDPC failed to obtain a majority, 88 of 180 seats, but Biya managed to form a coalition made up of representatives of minor and divided parties, amongst them exponents of the formerly rebellious UPC. ${ }^{7}$ The UNDP won 68 seats and remained in the opposition. John Fru Ndi boycotted the legislative elections, which meant that the SDF was not represented in the National Assembly from 1992 to 1997. But Fru Ndi decided to run personally in the fall presidential elections against Biya - and almost won. Officially Biya obtained $40 \%$ of the vote, Fru Ndi 36\%, and Maïgari $19 \%$. It is fair to assume that had it not been for massive manipulation of the vote Fru Ndi would have won (Ndi Mbarga 1993: 204-42; Onana 1994: 119-29).

The feeling that Biya and the governing coalition were not playing by democratic rules was reinforced by the municipal elections of January 1996. It was the first time in Cameroon's history that local elections were contested, and officially the RDPC did well. It secured 219 'mairies', the SDF 62, and the UNDP 29 (Le Messager 1996a). Many expected that the freely elected mayors and city councils would finally obtain real power. But disappointment followed: in the larger cities, where the opposition often has its strongholds, the government continued its practice of imposing a presidentially appointed 'délégué urbain' who exercises the real power. Once more the impression prevailed that Biya and his entourage were unwilling to accept the people's will. The legal battles that followed only served to confirm that idea.

The ruling elite did not intend to lose control over major cities. Perhaps for good reason, because the opposition had on various occasions been trying to organize massive urban strikes, called 'villes mortes', in English 'ghost towns' (Ndi Mbarga 1993: 155-68; Banock 1992: 56-64). In 1991, the action was relatively 
successful, although accompanied by violence; however a second attempt in May 1996 failed. An analysis of these protest movements shows that they were local as much as national in character, and that besides ethnic factors, changing demography also played a role. ${ }^{8}$

Further contests took place in 1997, with parliamentary elections once more being held in the first, and presidential elections in the second part of the year. Parliamentary elections took place on May 17, and of the 180 seats in the National Assembly, Biya's Rassemblement obtained 109. This time Fru Ndi's SDF participated and obtained 43 seats, while the share of Maïgari's UNDP was reduced from 68 to 13 seats, largely because of the SDF's participation. Four other parties got the remaining 8 seats. During and immediately following the elections there were once again allegations of irregularities, but in general the result appears to be a realistic reflection of the political forces prevailing at the time (Jeune Afrique Economie 1997a).

This cannot be said of the presidential elections held on October 12 - they were boycotted by the SDF and the UNDP. ${ }^{9}$ As a result Biya won an easy victory obtaining, according to official figures, $92.5 \%$ of the vote (Jeune Afrique Economie 1997b). Given the high turnout (around 80\%), the boycott seems to have backfired on the opposition parties. Since they could not agree on a coalition during the campaign, it is quite possible that the opposition perceived a boycott as the second-best solution, but the strategy did not pay off. Fru Ndi in particular has lost popularity, because his zig-zagging has been a bit too willful (Onana 1994: 106-10).

In December 1997, Biya reconstituted his government. There are 40 ministers and 11 state secretaries allowing, as usual, for a judicious distribution of posts among different ethnic groups. As part of Biya's 'démocratie appaisée' (Jeune Afrique 1999), the UNDP was back in government with three posts; Bello Bouba himself 
became Minister of Industrial and Commercial Development. The old north-south alliance has been reconstituted (Jeune Afrique Economie 1998a). Attempts to integrate the SDF have failed; Frau Ndi always was an outsider and has remained one. Officially there is disagreement over the establishment of an Independent Electoral Commission, but in fact 'le chairman' is having increasing difficulties maintaining the unity of his party.

\section{Economics}

Generally speaking, the years from independence to 1985 are considered to be an era of growth, whereas the ten years that followed are identified with the 'crise'. Only recently has there been another upswing. However, under closer examination things look different. Growth was always artificial, because it was mostly induced by government-promoted projects that in the meantime have largely failed. The standard of living for most Cameroonians is no better today than what it was at the time of independence. One cannot but agree with Bratton and van de Walle that in the long run, neopatrimonial rule is incompatible with growth. Let us look at Cameroonian economics in more detail.

Under Ahidjo the official development policy was planned liberalism. As a follower of de Gaulle and of France, the president consciously rejected socialism. Cameroon, in contrast to many other African countries, never opted for the neoMarxist road to development; it was always regarded as staunchly 'capitalist'. That did not prevent the state from being heavily involved in all aspects of economic life. A 'ministère du plan' would draw up Five-Year-Plans that, as one of their main purposes, facilitated the flow of outside assistance. As Jean-Claude Willame says, planned liberalism "was more a shopping list of desirable public sector investment projects for interested financing bodies and industrialists than the rigorous exercise in integrated financial, economic, and social allocation it 
was theoretically intended to be" (1986: 112).

The idea of buying turn-key industries was part and parcel of clientelism and the massive distribution of state resources. It tied the elites to the president by providing them with jobs, contracts and licenses; in return they had to demonstrate loyalty by participating in the political rituals of the UNC. As Willame implies, the Cameroonian elite preferred shopping to real development; after all, consumption is easier than production. ${ }^{10}$

By such methods, Cameroon set up around 150 enterprises with varying degrees of state participation; in most cases the state owned a controlling interest (Tedga 1990: 125-135). The companies were meant to supplement private initiative or to substitute for it where lacking. In reality, the enterprises frustrated private domestic initiative and often prevented the few truly modern managers from rising. Also, through planned liberalism the country was supposed to increase its independence by means of import substitution while initiating the diversification of imports, a strategy that has failed in many parts of the world. When oil revenues began to flow into the state till in the late 1970s, planned liberalism had its heyday. The state invested heavily in a number of ambitious industrial projects, and its international credit position promptly began to worsen.

Paul Biya inherited a large public sector. The state was the single most important employer; an enormous bureaucracy was in place that was supposed to manage development. According to van de Walle, state payrolls exploded from less than 20,000 at the time of independence to around 250,000 , including perhaps 80,000 in the parastatal sector (1994: 143). Under Biya the policy changed but only in name; it was now called communitarian liberalism (Ndi Mbarga 1993: 88-99). The period ended in 1985, when suddenly, and for a number of reasons, the economy went into a ten-year tailspin. 
Reliable statistics are difficult to obtain in sub-Saharan countries, and consequently it is nearly impossible to characterize the crisis in quantitative terms. When figures are cited anyway, they must be viewed with caution. However, according to the World Bank, real per capita GDP was cut in half between 1986 and 1993 (1995: 6), and for Rettinger, who uses figures from four different sources, the situation in 1992 was back to where it had been in the mid-1970s (1998: 17). Since the economy deteriorated further until 1995/96, we can understand why many felt that post-independence growth had been totally wiped out.

The financial sector was in particular difficulty (Rettinger 1998: 143-47). Major banks had closed their doors or were on the verge of bankruptcy. In 1995, the World Bank reported that half of the banks, representing $75 \%$ of the market, had serious liquidity problems (1995: 20). Furthermore, most public financial institutions were settled with so many poor loans that they, too, could not conduct normal business. The loans were largely those from parastatals, of course, which is a fair indication that political considerations were more important than commercial ones (Jeune Afrique Economie 1998b; Mutations 1997a).

To this day, the major obstacle to growth is lack of credit. In the past few years, total investment has been at an all-time low. Private investment, too, has sharply declined and often emanates from informal sources. Public investment, which in the early 1980s averaged $15 \%$ of the GDP, was down to $2.2 \%$ in 1993 . Today, Cameroon's rate of investment is substantially below the sub-Saharan average and far inferior to that of East and Southeast Asian countries (World Bank 1995: 9$30)$.

The overblown public sector has become a tremendous burden on the economy. Most state and parastatal enterprises are running heavy deficits and are hurting the economy. The World Bank, which usually uses diplomatic language, for once speaks plainly. It calls the financial results of public enterprises 'disastrous' and 
accuses them of 'bleeding' the private sector (World Bank 1995: 21, 26; Rettinger 1998: 124-43; Tedga 1990: 11).

This had been predicted for some time. The management of most public companies was poor, and particularly the various agro-industrial projects were in trouble from the start. A number of them never even got off the ground (Fotso 1994: 15964; Tedga 1990: 160-72). Insiders knew of the problems. Jean-Claude Willame, as early as 1986, showed that a whole string of Cameroonian parastatal enterprises was in great difficulty and that governmental policy was seriously flawed (1986: 111-132). Furthermore, as Willame adds, "the decision-making process has been pervaded by a lot of corruption generated at all levels, including the top of the administration, which was highly successful... in keeping government business under tight secrecy" (1986: 130). In the 1980s such criticism was rare, but today it is common, especially among ordinary Cameroonians!

Of course, economic decline also had its foreign sources. It is true that world market prices for some export crops fluctuated and that agriculture suffered. But that does not explain the wholesale disintegration of parastatal ventures, many of which have no ties to the world market whatsoever. Even the oil refinery constructed outside Limbe, and meant to supply Cameroon with its own cheap source of energy, has been a burden rather than a blessing to the country's economy.

Given the catastrophic performance of the public sector and the difficulties under which the private sector operates, it is no wonder that the informal sector is growing (ILO 1993: 5-6). Most people pursue some kind of economic activity outside the public and the private sectors. They keep busy from morning till night, but given the absence of sound policy and an effective institutional framework, their labor does not add up. Whether the informal sector can be turned into an engine for growth, as Hernando de Soto and some neo-liberals maintain, is questionable in sub-Saharan Africa. Studies that tend to support this viewpoint have been con- 
ducted in Latin America, the Middle East and Asia and do not automatically apply to Africa. ${ }^{11}$

The need for a structural reorganization of Cameroon's economy is obvious. During the 1997 elections, John Fru Ndi's SDF demanded a thorough liberalization of the economy, but the impetus for reform comes mainly from outside, from the IMF and the World Bank. As part of a debt-rescheduling effort, Cameroon agreed in September 1988 to a first Structural Adjustment Program (Mehler 1995: 295; Ndi Mbarga 1993: 125). As has become the rule, such programs include commercial, monetary, budgetary and structural measures. Cameroon's compliance was reluctant; of the four IMF agreements entered into up to 1996 none has been implemented as planned. Small wonder that the country has gained a reputation as a very disappointing 'adjuster' (Mehler 1995: 296).

In 1994, finally, abolishing export levies and price subsidies on traditional export crops liberalized commerce. In January 1994, a much needed currency devaluation took place, and exports have since increased. Budgetary discipline has remained uneven, but apparently the government pay roll has been reduced and tax collection improved. In typical Cameroon fashion, restructuring is proceeding at a snail's pace. In 1995, the government announced plans to liquidate over 60 public enterprises and to privatize another 100 at a rate of 10 per year, but no names or dates were published (World Bank 1995: 36-37). Two lists appeared in 1996 containing the names of 15 companies each, but until December 1996 only Hevecam (Société des hévéas du Cameroun/Cameroon Rubber Company) had actually been sold. Recently the pace has quickened; other companies have since been privatized or, as in the case of the national railroad, management contracts have been signed with European consortia.

The impact of these liberalization measures is as yet difficult to assess. Andreas Mehler, writing in 1995, is convinced that the effort has utterly failed (1995: 
295). It is too early for a final verdict, however. If the announced program of privatization is carried out, it is bound to have some positive effects. But SAP assessments in other African countries show that overall results are disappointing unless restructuring ist accompanied by a serious domestic commitment for reform. Sociologically speaking such efforts would have to be supported by local entrepreneurs and an emerging middle class. In Cameroon there is a respectable indigenous commercial class, and many business people have become prosperous. But given the clientelistic nature of politics, their business methods are equally personal. Credit, difficult to obtain from formal sources, is often organized informally among the members of the same clan or ethnic group, and since the courts cannot be relied on for the collection of debts, many transactions are in kind or cash.

\section{Public Administration}

As Robert Jackson and Carl Rosberg point out, colonial rule was bureaucractic, but postcolonial rule is not: it is personal (1982: 15-16). Cameroon's governmental institutions are therefore only public in name. In character they are largely personal and by modern standards inefficient. They are meant to maintain neopatrimonial rule but are incapable of providing a framework for growth. Economists and political scientists alike have come to realize that a solid institutional framework or 'good governance' is one of the most important conditions for the functioning of a market economy and for the generation of well being. ${ }^{12}$

The poor state of the Cameroonian public administration is legend. It is difficult, however, to obtain concrete evidence. Even Fuabeh Fonge, an anglophone Cameroonian who has recently published a study on the subject, has little hard data, and almost none on the 1980s and 1990s (1997: 295-322). However, there is some interesting new evidence compiled by Jeffrey D. Sachs of Harvard Univer- 
sity. In his survey of the economic competitiveness of 23 African countries, Cameroon placed 19th (1998: 17). The country gets low grades in areas like openness, finance, infrastructure and labor, but some of the lowest scores are in the areas of government and institutions. Out of 20 countries included in this section of the survey, Cameroon is ranked as shown (Sachs 1998: 97):

\begin{tabular}{|l|l|}
\hline Evaluation Criteria & Rank (out of 20) \\
\hline - competence of public sector personnel & 15 \\
- wasteful government spending & 18 \\
- tax evasion & 20 \\
- antitrust or antimonopoly policy & 18 \\
- commercial contract enforcement & 19 \\
- lawsuits against government & 19 \\
- lawsuits against other businesses & 19 \\
- willingness of citizenry to use courts & 18 \\
- effective police force & 18 \\
- strength and expertise of civil service & 17 \\
\hline
\end{tabular}

There is little doubt that from the viewpoint of investors the country rates extremely low and that governmental and institutional weaknesses are especially pronounced. In short, Cameroonian public service - including the legal system - is in no position to provide a framework for growth, let alone a framework for general social justice. In fact, the country suffers from the triple evils of excessive governance, bad governance and non-governance. All three are intertwined, of course.

By excessive governance, the sheer size of Cameroonian bureaucracy is meant 
and, directly related to this, its cumbersome procedures and unnecessary red tape. Many public offices are plainly overstaffed. The general secretariat of the National Assembly, to mention just one example, is packed with clerks who have no work for most of the year. It is true that the country inherited the unwieldy and highly hierarchical French system of administration, starting with the "chef du quartier' and reaching upward via 'maire', 'sous-préfet', 'préfet', 'gouverneur', 'ministre de l'administration territoriale', 'présidence' to, finally, the 'Président de la République' himself. But not everything can be blamed on the former colonial masters, because in France the same structures produced 'un état fort' instead of 'un état mou'. Furthermore, the French themselves have shown that their institutions can be adapted and become less rigid and centralized. The Cameroonians could have gone through the same learning process. After all, in the last forty years, hundreds of high-ranking Cameroonians have attended seminars all over the world and have been taught how to structure and manage modern bureaucracies - to no visible effect. The neopatrimonial 'culture' is too powerful (Médard 1979: 56-67, 74).

The enormous size of the civil service becomes glaringly visible every evening on national television: endless numbers of 'fonctionnaires' are shown attending pompous functions, generally to install one of their own in a new position. In the days of Ahidjo, such events were usually dedicated to the initiation of a new development project - that quickly degraded. There are fewer projects to inaugurate these days, and the ceremonies now appear to be largely self-congratulatory. Keeping plenty of uniformed officials is one of the state's important reasons for being.

Excessive governance is compounded by the addition of bad governance, which embraces both incompetence and corruption. Like many African countries, Cameroon experienced a shortage of civil servants immediately after independence. The Africanization of the 'fonction publique' happened quickly, however, but the 
production of competence did not keep up with the rate of appointments. As Willame argues, the deplorable history of state and parastatal enterprise can be explained in good part by sheer incompetence (1986: 130-32). The problem is not only a lack of training but also of arbitrary appointments. Some 'haut fonctionnaire' is always building up his own personal network of clients with little regard for qualifications or experience.

The situation is worsened by corruption. Private enrichment at public cost is routine in Cameroon, especially now that government salaries have been cut drastically in some instances; university professors, for instance, earn up to a third less. If one is to believe newspaper reports, corruption is very common at almost all levels of government (Mutations 1996; Mutations 1997b). Members of the 'présidence' and ministers and directors of public enterprises make off with large amounts of money; lowly officials have to make due with small amounts. ${ }^{13}$ In order to improve its credibility, the government launches anti-corruption campaigns at regular intervals.

Terms like kleptocracy or prebendalism are used to characterize the situation (Andreski 1970: 346-57). Whatever the label, the situation creates profound injustices. If 'everyone can be bought' the rich literally enjoy all the rights, and the poor obtain none. Equality and the idea of a public good become a farce, and the consequences for administration - and for economic growth - are disastrous. Competition is falsified when money changes hands to buy officials; importing and exporting become expensive, arbitrary and complex when every official transaction has its price. ${ }^{14}$

If Cameroon suffers from excessive governance, it is also plagued by the opposite, by non-governance. There are instances where public services simply disappear. The Yaoundé city buses ceased running some time ago, the 'Journal Officiel', supposed to contain all new governmental laws and regulations, has not 
been printed regularly for years, and when in February 1998200 people died in a gasoline explosion caused by railroad mismanagement, many governmental services simply did not respond (Jeune Afrique Economie 1998c). At times, government is semi-permanent. 'Le patron' may be unavailable for weeks, either because he is 'en mission' (generally meaning abroad) or because he happens to be 'en brousse' (meaning outside the capital). In the 'big man's' absence, government business rests. Government performance is therefore often stop-and-go, periods of intensive activity are followed by periods of total calm - and neglect. Instead of being systematic, government activity is intermittent and nonsustained.

There is much dynamism while a project is being initiated, and there is even more fanfare at its inauguration, but then 'dégradation' sets in. Physical and institutional decay is the rule, regular maintenance is the exception. As a result, the country is littered with institutional ruins, with agencies and buildings that have become dysfunctional. For Richard Sandbrook and for Christopher Clapham political decay is an omnipresent danger in Africa (Sandbrook 1985: 40; Clapham 1996: 161-274). I have already mentioned the general secretariat of the National Assembly; the Cameroonian Chamber of Commerce is yet another example, but many foreign sponsored development projects could also be cited. Even presidential residencies are suffering from neglect and ruin. Two former palaces, the colonial palace in the center of Yaoundé and Ahidjo's 'fortress' on top of Mont Fébé, are empty and falling apart.

During the last two years Cameroon has come under increasing pressure to reform its public administration. In July of 1997, the government signed an agreement with UNDP to conduct a comprehensive study of the situation and to elaborate recommendations for a program on good governance (Jeune Afrique Economie 1998d). It is too early to know the specifics of the program, and its implementation is several years off. However, what we do know about administrative 
reform in general is that external stimuli can only bear fruit when powerful internal support is forthcoming and neopatrimonial rule is scaled down. Whether this is the case in Cameroon remains to be seen.

\section{Neopatrimonialism and Cameroon}

This short review of Cameroon's politics, economics and administration shows that the country is a classical case of neopatrimonial rule. Both Ahidjo and Biya practiced presidentialism, built up an extensive clientelistic network to control a highly diverse country, and in order to obtain the loyalty of their clients, engaged in a massive redistribution of state resources. Typical of Cameroon is the state of the economy and of the public administration. Both are being sacrificed for patrimonial ends. On both scores Cameroon's performance is worse than that of some comparable countries - and yet its politics are relatively stable. Obviously, such a system cannot function in the long run, because the inherent contradictions are too sharp.

Cameroon's neopatrimonialism, therefore, produces its own pressures for regime change, and in this respect the country's performance is once again quite typical. As Bratton and van de Walle argue, it is the institutional legacy that determines neopatrimonial regime transition more than economic or international factors (1997: 41-45, 272-79). This is certainly true for Cameroon, where public unrest and the demand for political change occurred against the background of the 'crise'. This term has both an economic and a political dimension, and most would agree that the trouble is homemade. Most newspapers express this same perspective, and only an occasional official would disagree.

As a consequence, the regime change that occurred after 1992 closely follows the 
eight phases distinguished by Bratton and van de Walle. In the years prior to 1992 a crisis in political legitimacy (1) gradually built up, mainly because Biya's promises of improvement and liberalization had come to nothing. The discontent became manifest when a public protest (2) led by John Fru Ndi broke out in Bamenda. Initial government response (3) was negative; the protest was put down by force, and there were casualties. Next there was a politicization of the demands (4) raised by the Bamenda protesters, which entailed elite erosion in the sense that former insiders jumped onto the SDF bandwagon or started their own political parties.

Biya then undertook some political reforms (5) by legalizing the establishment of parties and by liberalizing the press. This was a limited move and often meant 'one step forward, two steps back' (6), because the actual exercise of the rights involved was constantly hampered. The demand for a national conference was denied, and instead there was a Tripartite Conference. The negotiations ended in constitutional reform (7) introducing innovations like greater regionalization, but reform was also seen as a dilatory move. In the meantime, Biya called for early presidential elections (8) and, as Bratton and van de Walle show, these cannot be categorized as 'founding elections' because the voting was neither free nor fair, the incumbent was not ousted, and the loser did not accept the result (1997: 197, 201-06). It was a case of 'rapid elections' meant to manipulate the transition in favor of the incumbent (Bratton and van de Walle 1997: 175-77).

Cameroon's transition was consequently flawed - some liberalization occurred, but democratization failed. The crucial election of 1992 was not accepted by the oppositon, and the 'big man' stayed in power. No wonder that the local press runs headlines like "multipartisme: déjà! démocratie: pas encore" (Challenge 1996). Most Cameroonians fully realize that the process was flawed and that no real transition was taking place. 
If democracy is defined as more than the mere winning of elections, the results are more modest yet. Some authors think democracy should imply the existence of a democratic mentality, a large middle class and a strong civil society; in short, a veritable democratic culture. By these standards it becomes even more obvious that Cameroon is far from being a democratic polity. Of the three stages of transition - liberalization, democratization and consolidation - the country remains within the first. Samuel Huntington is far off the mark when, based on completely unrepresentative GNP figures, he considers Cameroon to be well on the road to democracy and in the same league with Tunisia, Mexico or Malaysia (1991: 313). GNP statistics are no substitute for careful conceptual analysis and on the spot observation.

There is little doubt that most Cameroonians want democracy, and there is also no question that a change of power based on fair elections would be important for the country's development, particularly for the promotion of good governance. But given the deeply engrained neopatrimonial culture prevailing in all of subSaharan Africa, the introduction of democracy faces immense obstacles (Joseph 1997: 363-82). It is not surprising that much of the progress achieved between 1990 and 1994 has already been reversed or, as Bratton and van de Walle conclude, is "eroding" (1997: 233; Baker 1998: 115-27). The most probable outcome of the transition process, therefore, is not democratization or consolidation, but what the two authors call survival. It is an intermediate result located between a "reversal to authoritarianism“ and „the difficult process of consolidation“ (Bratton and van de Walle 1997: 235).

For Bratton and van de Walle, survival is again largely determined by the institutional legacy mentioned earlier, which in turn is characterized either by political participation or political competition. Experience with competition is considered more important for survival than a history of mere participation. Cameroon, unfortunately, has more experience with participation than with competiton. Ahidjo 
ended competitive elections when he set up the single-party system in 1972; from then on, Cameroon went through the usual „mass rituals of political participation“ (Bratton and van de Walle 1997: 273). The legacy is not ideal, but the odds for the survival of the present multiparty system and for incremental improvements are relatively good. This means that in the foreseeable future, the country will live with imperfectly contested elections and relatively free print media.

So much for the model developed by Bratton and van de Walle. Cameroon is an amazing fit, but there are a few peculiarities that the theory cannot account for. This is not a fault of theory since, as Kenneth Waltz told us many years ago, it deals with general categories and is not meant to explain and predict every single instance (1979: 1-17). It is quite an achievement, therefore, if the theory of Bratton and van de Walle is relevant for description, analysis and prediction of general phenomena. Yet there are variations and special cases among the 47 subSaharan states - and Cameroon is one of them.

It is not entirely surprising that Cameroon should merely 'survive' and embark on a middle course between reversal and consolidation, between a return to outright authoritarianism (including a possible military takeover) and real progress toward democracy. As mentioned earlier and as shown in terms of economic policy, Cameroon has an astounding record of muddling through, or of incrementalism, to use a term from the vocabulary of Bratton and van de Walle (1997: 273). How can this be explained?

It is my thesis that Cameroonian sluggishness is related to its cultural diversity. As I pointed out at the outset, the country knows an extremely large number of ethnic and religious groups and, to top it off, has the dual heritage of French and British colonization. And, as I will yet demonstrate, the pattern is particularly complex in politically sensitive areas like Douala or the Grassfields. Most other African countries are either more homogeneous or possibly split between two or 
three peoples. Either situation creates a different context for neopatrimonial rule and regime change. Let me develop the argument by beginning with a discussion of Cameroonian elite defection, say a few words about its qualitative and quantitative aspects, and then focus fully on diversity.

As the Bretton and van de Walle model would lead us to expect, there were indeed some prominent former members of Cameroon's rent-seeking elite among the defectors. The most obvious cases are Bello Bouba Maïgari and Amadou Ndam Njoya; both fit the mold perfectly. John Fru Ndi, however, the main exponent of the opposition, has a completely different background.

Bello Bouba held important jobs in the Ahidjo and Biya era and was a true insider for many years: under Ahidjo he was Minister of Economics, and under Biya he even served as Prime Minister, and he ended up prosperous. He left government and Cameroon in 1984, some say under a cloud, and lived in Nigeria until 1991. Once back, he became active in party politics, fought for the UNDP chairmanship and did well in the 1992 parliamentary elections. From this platform he conducted his opposition politics and is now back in government as Minister of Industrial and Commercial Development (Onana 1994: 75-86).

Ndam Njoya is a Bamun from the western Grassfields, was educated in France, was the first Director of the International Relations Institute of Cameroon at the University of Yaoundé, then Vice Minister of Foreign Affairs, and then, but only briefly, Minister of Education. He was much less of an insider than Bello Bouba, but as a relative of the Sultan of Fumban, he was a useful figure to co-opt. His government career was brief, however, and once sacked, he was never called back. Ndam Njoya, like Bello Bouba, was obviously waiting to get back in power - but he waits still. He lives in Fumban, where he was elected mayor in the municipals of 1996. 
While these two could be called typical defectors, the case of John Fru Ndi is different. He had never been in public office, let alone a minister or member of parliament. He had never had his 'hand in the till' and did not want to return to power. As a bookseller from anglophone Bamenda, he was a strictly local figure. It is just because of his modest background that he was much admired for having stood up to Biya. 'Le chairman' is a colorful populist who tends to campaign in pidgin, the lingua franca in a region so heavily split by colonial history - but it is not the language of the elite and national politics! It is true that various 'returnees' jumped on the SDF bandwagon, but it was Fru Ndi who confronted Biya in the crucial 1992 presidential elections and who almost won. The people voted for a fresh face and not for a typical defector.

It is also important to mention that as an anglophone and a Bamenda, Fru Ndi comes from the Grassfields and is ethnically close to the francophone Bamiléké. He consequently managed to find followers not only among his own people but also among large numbers of the Bamiléké at home or in the larger cities to which they have migrated. But, and this is crucial, Bamenda and Bamiléké elite defection was anything but massive. To many of his own elite members, John Frun Ndi remained 'an outsider among the outsiders' with whom they had difficulty identifying. A few discussions with officials in Baffoussam, the major city of the Bamiléké region, will convince any visitor of this fact.

To obtain a feeling for the excruciatingly complex ethnic situation, it is necessary to know more about the Bamiléké factor in Cameroonian politics. These peoples live in tightly knit and hierarchically organized communities called 'chefferies' and practice animistic cults. At home in the hilly Grassfields, they are successful farmers and produce a number of crops that they can export as far as Gabon. Many have become wealthy businessmen in the most diverse trades, but a good number have also gone into government and the professions. This has drawn them into the larger cities where, like most groups, they tend to live in their own 
'quartiers' while keeping in close touch with the 'chefs' at home (Warnier 1993: 19-196).

These characteristics have led to a number of stereotypes not dissimilar to those held about the Jews: Bamiléké are smart, industrious, successful, rich, conspiratorial, manipulate the economy, live in ghettos and worship strange spirits. Comments about these people must be viewed with caution precisely because the Bamiléké are an important factor in the Cameroonian political economy. Much of what is said expresses sheer prejudice. Van de Walle is honest when he admits that much of his own information on the Bamiléké is „mixed and anecdotal“ (1994: 148).

Obviously the Bamiléké are equally prone to developing stereotypes of the rest of the Cameroonians, especially of the 'Muslim north' and the 'Bantu south', terms that are enormous generalizations. It is easy for a Bamiléké to believe that first the 'northern Muslims held power', that now it is the 'southern Bantus' - and that the Bamiléké have been 'kept out'. It is true that the Bamiléké have so far not had 'their' president, and given the many anti-Bamiléké prejudices, it might indeed be problematic if they did. Many saw John Fru Ndi as a front man of 'Bami power' but, as shown, he is not really one of 'theirs'.

Furthermore, it is simply not true that the Bamiléké have been kept 'out of power'. Ahidjo and Biya have always entrusted Bamiléké with governmental posts. Since clientelistic networks create an intimate link between government and business, and since many Bamiléké are entrepreneurs, their barons profit handsomely from the system. The Bamiléké are classical clientelists, and that is why there has always been a co-opted Bamiléké elite, most of whom did not defect. It is therefore somewhat problematic when Bratton and van de Walle state that it was 'natural' for many Bamiléké businesssmen to opt for the opposition (1997: 167). If they mean the thousands of little businessmen, they may be right, 
but if they mean the co-opted barons, they are wrong.

In light of this, the following general statement by van de Walle about the Cameroonian elite is equally ambiguous: „While I do not suggest that conflicts within the state elite fully explain Cameroon's political crisis, I do argue that they were an important factor" (1994: 148). The question is how important: did the state elites, on the whole, accelerate the reform process or did they help Biya to stall? Were they pushing for a 'national conference' or were they behind the Tripartite Conference? It would be normal for many to behave in an opportunistic fashion, but the available information suggests that on the whole they were more conservative than rebellious.

This takes me back to the central argument: elite defection was anything but massive, even among the Bamiléké, and the main opposition leader was not even a typical defector (Mehler 1997: 102-25). And, as I have already indicated, it seems plausible that the relatively moderate rate of defection is related to Cameroon's cultural diversity and - most particularly - to a pattern of complexity prevailing in politically sensitive areas. Take the Grassfields as an example. On the one hand the peoples of the Adamawa Plateau are ethnically close, on the other hand they are highly divided. Most Bamiléké are francophone animists or Christians, Ndam Njoya's Bamun are francophone and Muslim, and Fru Ndi's Bamenda are anglophone Christians (Mveng and Beling-Nkoumba 1974: 133-156; Fanso 1989: 2457). Given this complexity, how realistic is it to expect a united 'western' elite ready to defect?

I am fully aware that complex diversity alone is no guarantee for stability, as Lebanon and Bosnia amply demonstrate. Once violence spreads in such places it can entail a veritable Hobbesian state of war, a conflict of 'all against all'. Yet such diversity may also moderate conflict. Not only can the fear of a Hobbesian outcome work as a deterrent, but highly differentiated groups do not bandwagon 
as easily as one, two or three. Given an astute neopatrimonial manipulator, this facilitates divide et impera, giving Ahidjo and Biya greater leeway to control possible defectors (Fogui 1990: 197-347). Neopatrimonial rulers in less diverse settings have fewer strings to pull. Once they lose control over a dominant group, or worse, over their own, escalation is probable. The cases of Rwanda and Burundi come to mind, but this may also apply to Liberia, Sierra Leone and some other failing states.

Ethnic diversity and complexity can also help to explain the general Cameroonian tendency towards conservatism - in substance and in style. By African standards the presidentialism of both Ahidjo and Biya can be categorized as low key; withdrawal from the scene or virtual disappearance is part of it. Also characteristic are exceedingly slow reactions to important events like elections: a Cameroonian president is seldom in a hurry to reshuffle his government or to give in to public demands of any kind. The drama of a 'national conference' would be completely out of style. A president is meant to 'keep court' in dignity and to weigh decisions carefully by consulting at length with his more important clients. Decorum and prestige are important; the feudal parallels are evident.

Such a president is in no hurry to implement 'structural adjustment'. He does not rush into negotiations with anyone, including France and the IMF. He also does not mind being seen as a 'poor adjuster' or 'poor privatizer'. The same applies to handling corruption: the 'prince' is tolerant and extremely patient, but once he acts the culprit is expelled in no uncertain terms, although one day he may be forgiven and reinstituted. Administrative reform is also slow. A dramatic reduction in the government payroll would not only endanger clientelism but damage the image of a beneficient lord as well.

Seen from this perspective ethnic diversity has the advantage of excluding dra- 
matic options and of promoting incrementalism and 'survival'. It is no guarantee, however, for the resolution of the contradictions between politics, economics and administration. Ethnic diversity alone does not resolve the basic neopatrimonial dilemma. Ahidjo and Biya have walked a precarious line between stability and instability - which both helped to produce.

\section{References}

Andreski, S. 1970. "Kleptocracy as a System of Government in Africa." In Heidenheimer, A. (ed.) Political Corruption, Readings in Comparative Analysis. New York: Holt, Rinehart and Winston.

Baker, B. 1998. "The class of 1990: how have the autocratic leaders of subSaharan Africa fared under democratisation?", Third World Quarterly, 19, 1.

Banock, M. 1992. Le processus de démocratisation en Afrique, Le cas camerounais. Paris: L'Harmattan.

Bayard, J.-F. 1985. L'Etat au Cameroun. Paris: Presses de la Fondation Nationale des Sciences Politiques.

Borner, S., Brunetti, A. and Weder B. 1994. Political Credibility and Economic Development. London: Macmillan.

Boulaga, F. 1993. Les conférences nationales en Afrique noire. Paris: Karthala.

Boulaga, F. 1997. La démocratie de transit au Cameroun. Paris: L'Harmattan.

Bratton, M. and van de Walle, N. 1997. Democratic Experiments in Africa, Regime Transition in Comparative Perspective. Cambridge: Cambridge University Press.

Chazan, N., Mortimer, R. and Ravenhill, J. 1992. Politics and Society in Contemporary Africa. Boulder: Lynne Rienner.

Clapham, C. 1996. Africa and the International System, The Politics of State Survival. Cambridge: Cambridge University Press.

Eboua, S. 1996. D'Ahidjo à Biya, Le changement au Cameroun. Paris:

L'Harmattan. 
Fanso, V. 1989. Cameroon History For Secondary Schools and Colleges Vol. 1. London: Macmillan.

Fogui, J.-P. 1990. L'intégration politique au Cameroun: Une analyse centrepériphérie. Paris: Librarie générale de droit et de jurisprudence.

Fonge, F. 1997. Modernization without Development in Africa, Patterns of Change and Continuity in Post-Independence Cameroonian Public Service. Trenton: Africa World Press.

Fotso, V. 1994. Le Chemin de Hiala. Paris: Editions de Septembre.

Harbeson, J., Rothchild, D. and Chazan, N. (eds.) 1994. Civil Society and the State in Africa. Boulder: Lynne Rienner.

Huntington, S. 1991. The Third Wave, Democratization in the Late Twentieth Century. Norman: University of Oklahoma Press.

ILO (Organisation internationale du travail) 1993. "L'état et le secteur nonstructuré au Cameroun." Addis Abeba: Programme des emplois et des compétences téchniques pour l'Afrique (PECTA).

Jackson, R. and Rosberg, C. 1982. Personal Rule in Black Africa, Prince, Autocrat, Prophet, Tyrant. Berkeley: University of California Press.

Joseph, R. 1999. “Autocracy, Violence, and Ethnomilitary Rule in Nigeria.” In Joseph R. (ed.) State, Conflict, and Democracy in Africa. Boulder: Lynne Rienner.

Le Vine, V. 1986. "Leadership and Regime Change in Perspective". In Schatzberg M. and Zartman I. (eds.). The Political Economy of Cameroon. New York: Praeger Publishers.

Mbock, C. 1990. Cameroun, Le défi libéral. Paris: L'Harmattan.

Médard, F. 1977. "L'état sous-développée au Cameroun”, L’Année Africaine, June.

Mehler, A. 1995. "Politische Hindernisse der Strukturanpassung in Kamerun." In Beth J. (ed.) Politische Restriktionen der Strukturanpassung in Entwicklungsländern. Hamburg: Deutsches Übersee-Institut.

Mehler, A. 1997. “Cameroun: une transition qui n'a pas eu lieu.” In Quantin J.-D. 
and P. (eds.) Transitions démocratiques africaines. Paris: Karthala.

Mveng, R. and Beling-Nkoumba D. 1974. Manuel d'histoire du Cameroun. Yaoundé: Editions CLE.

Ndi Mbarga, V. 1993. Ruptures et continuités au Cameroun. Paris: L'Harmattan.

Ngayap, P. 1983. Cameroun: Qui gouverne? Paris: L’Harmattan.

Ngniman, Z. 1996. Nigéria Cameroun, la guerre permanente? Yaoundé: Editions CLE.

Onana, H. 1994. Les transitions démocratiques en Afrique: Le cas du Cameroun. Yaoundé: CEPER.

Prouzet, M. 1974. Le Cameroun. Paris: Pichon \& Durand-Auzias.

Rettinger, D. 1998. Die Wirtschaftsprobleme Kameruns, Eine Untersuchung der Bedeutung von Institutionen für den Entwicklungsprozess. Frankfurt a/Main: Peter Lang.

Rothchild, D. 1999. "Ethnic Insecurity, Peace Agreements, and State Building." In Joseph R. (ed.) State, Conflict, and Democracy in Africa. Boulder: Lynne Rienner.

Sachs, J. 1998. The Africa Competitiveness Report 1998. Cambridge and Geneva: Harvard Institute for International Development.

Sandbrook, R. 1985. The Politics of Africa's Economic Stagnation. Cambridge: Cambridge University Press.

Takougang, J. and Krieger, M. 1998. African State and Society in the 1990s, Cameroon's Political Crossroads. Boulder: Westview Press.

Tedga, P. 1990. Entreprises publiques, Etat et crise au Cameroun. Paris: L'Harmattan.

van de Walle, N. 1994. "Neopatrimonialism and Democracy in Africa, with an Illustration from Cameroon." In Widner J.A. (ed.) Economic Change and Political Liberalization in Sub-Saharan Africa. Baltimore and London: The Johns Hopkins University Press.

Waltz, K. 1979. Theory of International Politics, New York: McGraw-Hill. 
Warnier, J.-P. 1993. L'esprit d'entreprise au Cameroun, Paris: Karthala.

Willame, J.-C. 1986. "The Practice of a Liberal Political Economy: Import und Export Substitution in Cameroon (1975-1981)", in Schatzberg, M. and Zartman I. (eds.) The Political Economy of Cameroon. New York: Praeger Publishers.

Wold Bank 1995. "République du Cameroun, Le défi: mettre en valeur des ressources inexploitées, Evaluation du secteur privée," Washington: Report No. 13955-CM, 31 August.

Zang-Atangana, J.-M. 1989. Les forces politiques au Cameroun réunifié. Paris: L'Harmattan.

\section{Newspapers}

Challenge 1996: 24-30 December, 9.

Jeune Afrique 1999: 2-8 March, 40-42.

Jeune Afrique Economie 1997a: 2 June, 64-74.

Jeune Afrique Economie 1997b: 3-16 November, 88-89.

Jeune Afrique Economie 1998a: 5-19 January, 86-92.

Jeune Afrique Economie 1998b: 29 June-19 July, 36-38.

Jeune Afrique Economie 1998c: 2-15 March, 6-7, 86-92.

Jeune Afrique Economie 1998d: 19 October-1 November, 76-77.

Le Messager: 15 February 1996, 6.

Mutations 1996: 26-30 December, 8.

Mutations 1997a: 6-12 January, 4.

Mutations 1997b: 6-12 January, 11 
1 Tribal, cultural and racial terms are often mixed when enumerating the many peoples; Prouzet speaks of racial groups and mentions "bantous, semi-bantous, hamites, sémites, soudanais" (see Prouzet 1974: 10).

2 At present, the Prime Minister is an anglophone from South-West Cameroon: Peter Mafany Musonge. Another recent example was Simon Achibi Achu.

3 Biya changed the country's name back to "République du Cameroun", the designation used from independence to the reunification with West-Cameroon and the instauration of the Federal Republic in 1961.

$4 \quad$ Federalism is a constant issue in Cameroonian politics, which shows in the fact that the newly amended constitution makes provision for the creation of a second chamber, a Senate, intended to represent the various regions more strongly (see Bratton and van de Walle 1997: 77-82).

5 On the general issue of civil society in Africa see Harbeson, Rothchild and Chazan 1994: 1-100. As Sandbrook points out, there is also no class base for strong associations; Africa has at best embryonic classes (1985: 68). See also Eboussi Boulaga 1997: 317-433.

6 Today there are about 20 regularly published newspapers, many of them weeklies. The more important newspapers in 1997-98 were: Mutations (Yaoundé), Le Messager (Douala), La Nouvelle Expression (Douala), Challenge (Douala), Génération (Yaoundé), Le Front Indépendant (Douala), The Herald (Yaoundé), Cameroon Post (Buea/Douala), and the governmental Cameroon Tribune (Yaoundé). Press freedom is not perfect, however, as the ,affaire Njawe‘ has amply demonstrated (see Jeune Afrique, 20-26 January 1998: 9-11)

7 An amnesty allowed exponents of the formerly rebellious UPC to return from exile and to run for office. Some „upécistes“ made it into parliament, and some were given important government jobs. However, quarrels tore the party apart, so that today the once proud opposition group is hardly a serious challenger. For more details on the party's history see ZangAtangana 1989: 77-176. 
In Douala there are numerous refugees from many parts of Africa, and there is a large Nigerian colony. Because of the military conflict between Nigeria and Cameroon over the Bakassi Penninsula, the government is anxious not to lose control over important parts of the coastal region. For more details on the Bakassi conflict, see Ngniman 1996. For a detailed discussion of the problem of internal minorities, or of "allogènes" as they are now called, see La Nouvelle Expression, 23 Mai 1996, "Minorités, autochtones, allogènes et démocratie" (entire issue).

9 This decision came as a surprise to many since, after the parliamentary election, the SDF formed a common front with the president's Rassemblement in choosing the leadership of the new Assembly. Biya's party got the presidency and three of the five vice-presidential posts, and the SDF obtained the remaining two. In addition, the SDF obtained the chairs of some committees (Jeune Afrique Economie, 14 July 1997, pp. 34-36; 6-19 October 1997, pp. 7478).

10 For a contrast, read Fotso 1994. Fotso is one of the most successful Cameroonian entrepreneurs, a self-made man.

11 For a neo-liberal discussion, see Hernando De Soto, The Other Path: The Invisible Revolution in the Third World, London: Tauris 1989; A. Lawrence Chickering and Mohamed Salahdine (eds.), The Silent Revolution, The Informal Sector in Five Asian and Near Eastern Countries, ICS Press, San Francisco CA 1991.

12 The „discretionary state“ is often cited as the worst enemy of growth - and the predictable and transparent enforcement of rules is said to bit its best friend. Fore more details see Borner, Brunetti and Weder 1994; 12-13: Rettinger 1998: 167-250.

13 Allegations about corruption at highest levels are common; anti-corruption campaigns are also frequent. In 1997, the Edzoa Tituts affair was making headlines. For many years Edzoa was very close to Biya, served as his personal doctor and occupied some of the most influential positions. In a move that surprised everyone, he voluntarily resigned from his post as Minister of Public Health ? only to announce that he was running for president! A few weeks later he was arrested. Rumors about improper financial dealings had been circulating for 
years. For details, see Jeune Afrique Economie, 20 October - 2 November 1997, pp. 80-84.

14 The port of Douala is a typical example. The Douala Port Authority became so inefficient that the government decided to hand important functions over to the Société Générale de Surveillance (SGS), operating internationally out of Geneva: Le Messager, 2 January 1997, p. 6, "La SGS à l'heure du bilan". But that alone did not help, and in the meantime more serious measures have had to be taken; see Jeune Afrique Economie, 2 - 15 February 1998, pp. 34-35. 